\title{
Activity of Alveolar, Peritoneal Macrophages and Blood Phagocytes during Experimental Infection of BALB/c Mice with MHV-Šumava
}

\author{
I. SPIŠŠÁKOVÁ, ${ }^{2} \mathrm{~K}$. VAJOVÁ, ${ }^{1} \mathrm{M}$. HRICOVÁ, ${ }^{1} \mathrm{~J}$. MISTRÍKOVÁ,,${ }^{1,2}$ \\ ${ }^{1}$ Department of Microbiology and Virology, Faculty of Natural Sciences, Comenius University, \\ Mlynská dolina B2, 84215 Bratislava, Slovak Republic \\ 2Institute of Virology, Slovak Academy of Sciences, Dúbravská cesta 9, 84245 Bratislava, Slovak Republic
}

Received August 25, 2004

Accepted August 30, 2005

\begin{abstract}
Spiššáková I., K. Vajová, M. Hricová, J. Mistríková, J.: Activity of Alveolar, Peritoneal Macrophages and Blood Phagocytes during Experimental Infection of BALB/c Mice with MHV-Šumava. Acta Vet. Brno 2005, 74: 353-359.

MHV-Šumava (MHV-Š) represents murine gammaherpesvirus. Experimental intranasal infection of BALB/c mice with MHV-Š caused leukocytosis and increased number of alveolar macrophages. Atypical blastic leukocytes were observed. The number of alveolar macrophages correlated with the amount of MHV-S in lungs. Macrophages have been identified as the major reservoir of latent virus in peritoneal exudate cells (PECs). Using indirect immunofluorescence method we have found the number of CD14 positive cells correlating with the number of MHV-Š antigen positive PECs MHV-Š infected leukocytes were found to have significantly reduced phagocytic activity. As evaluated by quantification of digested Candida albicans we observed slightly increased phagocytic index of infected leukocytes compared to controls. Taken together, we proved a decrease in ability of these cells to phagocyte due to MHV-Š infection.
\end{abstract}

Murine gammaherpesvirus, MHV-Šumava, infection, latency, PECs, macrophages, phagocytic activity

The murine herpesvirus isolate Šumava (MHV-Š) is an oncogenic gammaherpesvirus which serves as a model for the study of pathogenesis and immunology of human gammaherpesviruses (Mistríková et al. 2002). MHV-Š was isolated from the lungs of seropositive Apodemus flavicollis (Mistríková and Blaškovič 1985) and represents one of the eight isolates of mouse gammaherpesviruses. Isolates MHV-60, 68, 72, 76 and 78 are widespread in population of free living rodents (Blašk ovič et al. 1980) as well as those isolated later such MHV-4556, MHV-5682 (Kožuch et al. 1993). All isolates represent one group of antigenically identical viruses (S v ob od ová et al. 1982), however, MHV-Š differs from other MHV isolates in minimal 3 polypeptides (Reichel et al. 1991). When administered intranasally the MHV-68 virus replicates in the lungs. Spread then occurs in the B-cell compartment resulting in splenomegaly. The virus then becomes latent in B-cells and persists. The long-term infection is associated with the development of lymphoproliferative disease (Sunil-Chandra et al. 1994). Particular studies of peripheral blood adherent mononuclear cells (AMCs) infected with MHV-72 in vivo and in vitro confirmed their important role for dissemination and latency of the virus in organism. It was found that the peripheral blood AMCs from non-infected mice were permisive to MHV-72 infection. AMCs play an important role in latency and reactivation of latent virus. Important are findings of increased virus neutralization antibodies in correlation with activation of latent virus (Mistrík ová et al. 1994). The aim of this work was to confirm our previous observation (Mistrík ová et al. 1994) about importance of peritoneal macrophages in chronic phase of infection on the model of BALB/c mice experimentally infected with MHV-72. Our main aim was to (i) quantify alveolar

Address for correspondence:

Mistríková Jela

Department of Microbiology and Virology, Faculty of Natural Sciences,

Comenius University, Mlynská dolina B2, 84215 Bratislava, Slovak Republic

Institute of Virology, Slovak Academy of Sciences,

Dúbravská cesta 9,842 45 Bratislava, Slovak Republic

Tel.: 00421254773172

Fax: 00421260296436

E-mail: virumis@savba.sk

http://www.vfu.cz/acta-vet/actavet.htm 
macrophages in broncho-alveolar area in acute MHV-Š infection and so prove the correlation with the amount of virus in the lungs, (ii) detect viral antigen in infected cells with specific monoclonal antibodies using the method of indirect immunofluorescence and monitored the kinetics of Ag+ cells in PECs and spleen after MHV-Š infection, (iii) examine phagocytic efficiency of leukocytes after infection with MHV-Š as a new model for EBV.

\section{Materials and Methods}

Mice

Female BALB/c mice were obtained from the Institute of Virology of the Slovak Academy of Sciences and infected at 4-6 weeks of age.

Virus

MHV-Š was isolated by (Mistrík ová and Blašk ovič 1985). Virus working stocks were prepared by infection of VERO cells.

Infection of mice

Female (4 - 6 weeks old) BALB/c mice were inoculated with $2 \times 10^{5}$ PFU MHV-Š per mouse. Twenty $\mu$ lof the virus was administered intranasally (i.n.) to mice under light ether anaesthesia.

Sampling

Mice were killed at different times p.i. by cervical dislocation. The blood, alveolar macrophages, spleen and peritoneal macrophages were removed and used for preparation of cell suspensions for detection of viral antigen.

Blood samples

Were taken from sinus orbitalis at different times p.i. for preparing of serum and for examination of leukocytes. Obtained sera were inactivated at $56^{\circ} \mathrm{C}$ for $30 \mathrm{~min}$ and titrated.

Staining of blood leukocytes

Blood smears were made immediately after blood collection. After fixation by air drying they were stained with May-Grünwald solution for $10 \mathrm{~min}$ and Giemsa Romanowski solution for $15 \mathrm{~min}$. Number of leukocytes was determined after 10 min of staining with Türk solution.

Differential white blood cell count

Blood picture consisted of calculation of percentage of each kind of white blood cells.

Immunofluorescence (IF) test

The presence of the virus antigen and surface antigen in cells from organs of infected mice was determined by indirect immunofluorescent assay.

Monoclonal antibodies (MoAbs)

Mouse MoAbs prepared against MHV-Š was diluted $1: 100-500$ and vizualized with goat anti mouse IgG $(\mathrm{H}+\mathrm{L})$ conjugated with rhodamine (Immunotech, Slovak Republic). Rat MoAbs to mouse CD14 monocytes were purchased from Pharmingen (USA) and diluted 1: 50. A goat anti rat $\operatorname{IgG}(\mathrm{H}+\mathrm{L})$ conjugated with fluoresceinisothiocyanate (Sigma) was used as the secondary antibody. All the antibodies were diluted in bloking solution before use. Mouse MoAbs reacted with denatured viral antigen in Western blot and showed specificity for 50-55 000 protein. This MoAb exhibited virus-neutralizing potency indicating that the 50-55 000 viral antigen might be relevant for the infectivity of MHV (Matušková et al. 2003).

Virus neutralization test (VNT)

was performed with 2-fold dilutions of sera from infected mice to which 1000 ID of appropriate virus was added. The virus-serum mixtures were incubated at $37^{\circ} \mathrm{C}$ for $90 \mathrm{~min}$ and then inoculated into 24 - 48-hr-old VERO cell cultures according to the growth requirements of the respective virus. The titre was calculated when 1000 ID of virus caused a complete CPE in infected cells used as controls.

Determination of phagocytic efficiency

The phagocytic efficiency was examined via co-incubation of leukocytes altogether with inactivated Candida albicans at the ratio of $1: 5$. The same volumes of $C$. albicans, heparinized blood, autologous serum and Hank's solution were mixed together and incubated for $30 \mathrm{~min}$ at $37^{\circ} \mathrm{C}$ at continual mixing to provide precise opsonization. The smears were then stained with Wright's solution and neutral water and determined the phagocytic activity (FA) and phagocytic index (FI). FA was calculated as percentage of phagocytes out of 100 examined able to phagocyte $C$. albicans. FI was calculated as average number of $C$. albicans being phagocyted by one phagocytic cell.

Statistical analysis

Statistical significance of differences was assessed using Student's $t$-test. 


\section{Results}

Since the MHV-Š infection was lethal for newborn suckling mice (Mistríková et al. 2002), we decided to infect $4-6$ week-old mice. In our experiment 50 female BALB/c mice were used, 25 served as controls and 25 were inoculated with MHV-Š with $2 \times 10^{5} \mathrm{PFU}$ per mouse. Twenty $\mu \mathrm{l}$ of virus was administered intranasally (i.n.) to mice under light ether anaesthesia. Infected mice did not show apparent symptoms of illness. However, they showed an increase in the number of leukocytes and appearance of atypical leukocytes in peripheral blood. In the first part of our work presented here, mice infected with MHV-Š were sacrificed during 27 days of acute infection and 90 and 240 days of chronic infection. Using monoclonal antibodies against MHV-Š via immunofluorescent method we detected viral antigen in immunocompetent cells from the samples from lymphatic organs. Table 1 shows that in acute infection the highest number of cells positive on viral antigen were

Table 1. Detection of viral antigen MHV-Š in lymphatic organs of infected BALB/c mice

\begin{tabular}{|l|c|c|c|c|c|c|}
\hline & \multicolumn{5}{|c|}{ Acute infection } & \multicolumn{2}{c|}{ Chronic infection } \\
\cline { 2 - 7 } & 2 d.p.i. & 7 d.p.i. & 14 d.p.i. & 27 d.p.i. & 90 d.p.i. & 240 d.p.i. \\
\hline $\begin{array}{l}\text { Peripheral } \\
\text { blood }\end{array}$ & + & ++ & + & + & - & - \\
\hline $\begin{array}{l}\text { Alveolar } \\
\text { macrophages }\end{array}$ & ++ & +++ & +++ & + & - & - \\
\hline Spleen & - & + & + & ++ & + & - \\
\hline PECs & - & - & - & + & + & ++ \\
\hline
\end{tabular}

\begin{tabular}{|l|c|c|c|c|c|c|}
\hline VNT & $1: 16$ & $1: 64$ & $1: 256$ & $1: 128 / 256$ & $1: 64 / 128$ & $1: 128$ \\
\hline
\end{tabular}

Viral antigen was detected using MoAb against MHV-· via immunofluorescent test

$$
\begin{aligned}
& -0 \%+2-4 \% \\
& \pm 1 \%++\quad 5-10 \% \\
& +++50 \%
\end{aligned}
$$

present in alveolar exudate peaking in period from day 7 to day 14 p.i. with positivity more than $50 \%$. In the same intervals as harvesting the samples for the IF test, using virus neutralization test (VNT) we examined sera. The antibodies against virus reached a maximum of $1: 256$ on day 14 p.i. During the acute infection, the number of leukocytes increased, peaking with 14700 on day 14 p.i. Atypical leukocytes were observed in differential white blood cell counts, reaching a maximum of $14 \%$ on day 9 p.i. (Fig. 4).

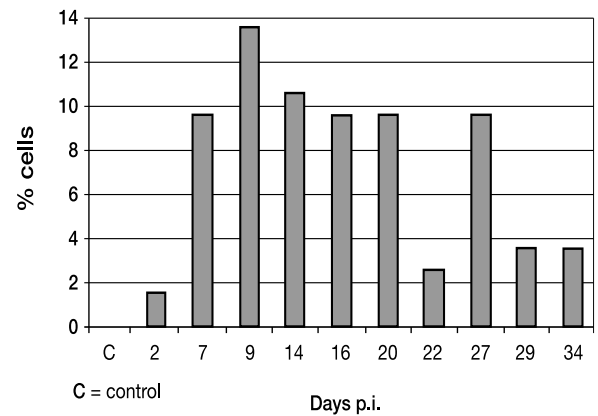

Fig. 4. Appearance of atypical forms of leukocytes in

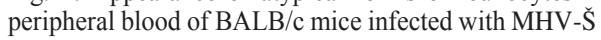

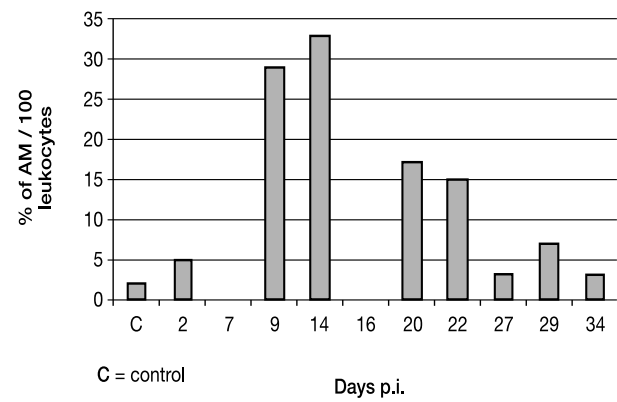

Fig. 5. The amount of alveolar macrophages (AM) of BALB/c mice infected with MHV-Š 


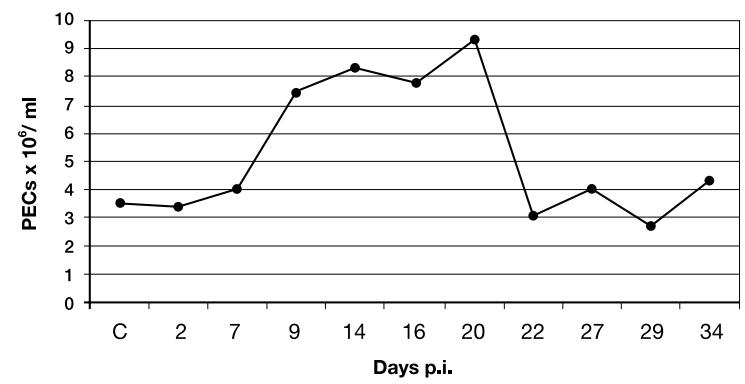

Fig. 6. The amount of PECs obtained from BALB/c mice infected with MHV-Š in relation to day p.i.

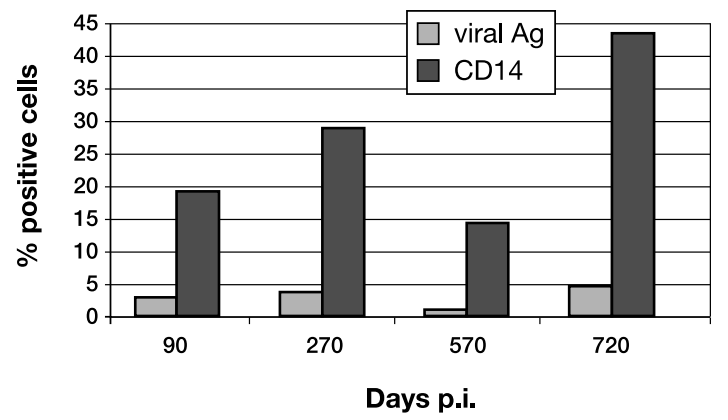

Fig. 7. Number of CD14 and virus Ag positive cells in relation to days p.i. in chronic in fection

Intranasal inoculation with MHV-Š led to an initial lung infection with peak titres of virus in lungs, which were accompanied with increased number of alveolar macrophages in alveolar exudate (Fig. 5). Alveolar monocytes and macrophages are crucial for the virus, since they become the main target and the place of viral replication after the first contact with its host. Further, we investigated the number of cells in peritoneal exudate. We found that the number of PECs kept an increased level from day 9 to day 20 p.i. (Fig. 6). PECs consisted of heterogenic cell population such as lymphocytes, monocytes and macrophages (Plate V, Fig. 1). Detecting CD $14^{+}$cells via IF test we proved that macrophages represented the major part of PECs. Using MAbs against MHV-Š we detected the presence of viral antigen in these cells (Plate V, Fig. 2). Our intention was to find relationship between the number of CD14 positive PECs and number of cells positive on viral Ag. We focused on chronic infection from day 90 up to 720 p.i. As Fig. 7 shows the number of CD14+ cells peaked on day 720 as well as number Ag+ cells suggesting viral reactivation. As well known, the spleen harbours virus in a latent form in B lymphocytes, however the major reservoir of the latent virus are macrophages in peritoneal cells. Using IF test we compared the presence of viral antigen in splenocytes and PECs during the late phase of chronic infection in order to confirm meaning of PECs, macrophages particularly, as major reservoir even in infection of MHV-Š. The samples were taken 150, 240 and 570 days post infection.

In peripheral blood, we examined the efficiency of leukocytes to phagocyte during acute infection and chronic infection, particularly. Using co-incubation with Candida albicans we determined phagocytic activity (FA) and phagocytic index (FI) non-infected controls as well as infected groups in acute and chronic stage of infection. The average values of FA and FI are shown in Table 2 . In control group FA $=78 \%$ and $F I=5.1$. During acute phase $F A=41 \%$, 
Table 2. Phagocytic efficiency of leukocytes obtained from non-infected controls and infected $\mathrm{BALB} / \mathrm{c}$ mice

\begin{tabular}{|c|c|c|}
\hline Mice (No.) & FA & FI \\
\hline non-infected controls (5) & $78 \% \pm 0.15$ & $5.1 \pm 0.78$ \\
\hline acute infection (3) & $41 \% \pm 0.01$ & $5.35 \pm 0.4$ \\
\hline chronic infection (8) & $58.8 \% \pm 0.18$ & $5.3 \pm 0.14$ \\
\hline
\end{tabular}

$\mathrm{FA}=$ phagocytic activity

$\mathrm{FI}=$ phagocytic index

which indicate significant decrease of phagocytic activity comparing to controls. Slightly increased value was detected in FI $=5.35$. In chronic phase of infection we monitored phagocytic efficiency $\mathrm{FA}=58.8 \%$ and $\mathrm{FI}=5.3$.

\section{Discussion}

Pathogenetic studies of MHV demonstrate that after acute infection the virus causes chronic infection and is capable of reactivation forming tumors. Components of host immune system are actively involved in all phases of MHV infection and play a key role in latency and following reactivation. Although little is known about the mechanism of MHV68 transmission, the early stages of infection after intranasal inoculation and the ensuing antiviral host immune response have striking similarities with EBV. After intranasal infection the virus establishes a lytic infection. It is rapidly cleared by the host immune response with $\mathrm{CD} 8+\mathrm{T}$ cells playing a prominent, but not exclusive role. Latency is established largely in splenic B-cells, although other cell type can harbour latent virus (Blackman et al. 2000). This was proved by Flaňo et al. (2000), who showed that latent MHV-68 is harboured in three types of cells in spleen after intranasal infection, namely, B-cells, macrophages and dendritic cells. Our results show that the infection with MHV$\breve{S}$ was accompanied by major changes in number as well as in morfology of leukocytes. Compared to isolates MHV-72 (Mistríková et al. 1994) and MHV-78, (Mrmusová Šupolíková et al. 2003) the profile and the percentage of Ag+ cells is similar, particularly with MHV-78. In previous experiments we found, that during 180 - 240 days p.i. MHV-72 persisted in the highest titre in peritoneal macrophages. VNT antibodies showed an increase in the same interval as reactivation of latent virus (Mistrík ová et al. 1994). Mistríková et al. (1994) and Weck et al. (1999) demonstrated that macrophages (F4/80+) in PECs harbour latent MHV-72, MHV-68 and are the major reservoir, comparing to B-cellreservoir, where the frequency of $\mathrm{CD} 19^{+} \mathrm{B}$-cells carrying latent virus was 10 -fold lower. This fact puts B-cells into position of the second reservoir of latency. Little is known about the interaction of EBV with human monocytes. Savard et al. (2000) demonstrated that EBV infects and replicates in human monocytes, a process accompanied by the supression of phagocytosis by these cells. The results indicate that the virus adsorbs and penetrates into monocytes without being phagocytosed. EBV-infected monocytes are significantly impaired in their ability to phagocyte. Impairment of the phagocytosis machinery is expected to be advantageous for the viral outcome (S a vard et al. 2000). Taken together, it can be postulated that targeting monocytes/macrophages may represent an evolutionary advantage for ensuring propagation and persistance of EBV and other herpesviruses within the host (Blasig et al. 1997; Kondo et al. 1991; Larsson et al. 1998; Maciejewski et al. 1993). Shimakage et al. (1999) in his study provides additional indications that monocytes/macrophages may serve as reservoirs of EBV infection. EBV-infected monocytes showed reduced capacity to phagocyte. The mechanisms by which EBV affects phagocytosis remain to be elucidated (Savard et al. 2000). Results demonstrated in our study show similarities with those of other authors, who proved suppressive effect of human 
herpes viruses on phagocytic activity. Decreased phagocytic efficiency caused by herpes viruses allows intensive replication and establishment of different forms of infection typical for them. Our results presented here confirm the important role of peritoneal macrophages in chronic infection of MHV-Šumava and point out eminent effect of the infection on phagocytic efficiency of macrophages. Similar results obtained in EBV studies confirm suitability of murine herpesvirus as an animal model.

\section{Aktivita alveolárnych, peritoneálnych makrofágov a krvných fagocytov $v$ experimentálnej infekcii BALB/c myši vírusom MHV-Šumava}

MHV-Šumava predstavuje myšací gamaherpesvírus. Experimentálne sme infikovali inbrédnu líniu BALB/c myš́i intranazálne, čo u nich vyvolalo leukocytózu, zvýšenie počtu alveolárnych makrofágov a prítomnost atypických leukocytov v periférnej krvi. V plúcach sme zistili koreláciu medzi počtom alveolárnych makrofágov a množstvom MHV-Š. V bunkách peritoneálneho výplachu (PECs) boli makrofágy identifikované ako hlavný rezervoár latentného vírusu. S použitím špecifických monoklonálnych protilátok voči MHV-Š sme v PECs pomocou imunofluorescenčnej metódy detegovali vírusový antigén a pozorovali koreláciu medzi bunkami pozitívnymi na marker CD14 a bunkami pozitívnymi na antigén MHV-Š. Leukocyty infikované MHV-Š vykazovali signifikantne zníženú fagocytárnu aktivitu a kvantifikácia pohltených Candida albicans v porovnaní s kontrolnými vzorkami ukázala mierne zvýšenú hodnotu fagocytárneho indexu.

\section{Acknowledgement}

This work has been supported by grant N.1/93 11/02 and 1/00 22/03 of the grant agency of the Ministry of Education of Slovak Republic.

\section{Note}

The authors claim that all procedures using animals were performed in accordance with the European convention for the protection of vertebrate animals used for experimental and other scientific purposes from 1986.

\section{References}

BLACKMAN MA, FLAŇO E, USHERWOOD E, WOODLAND DL 2000: Murine gammaherpesvirus-68: a mouse model for infectious mononucleosis. Mol Med Today 6: 488-490

BLASIG C, ZIETZ C, HAAR B, NEIPEL F, ESSER S, BROCKMEYER HN, TSCHACHLER E, COLOMBINI S, ENSOLI B, STURZ, M 1997: Monocytes in Kaposi's sarcoma lesions are productively infected by human herpesvirus 8. J Virol 71: 7963-7968

BLAŠKOVIČ D, STANČEKOVÁ M, SVOBODOVÁ J, MISTRÍKOVÁ J 1980: Isolation of five strains of herpesviruses from two species of free living small rodents. Acta Virol 24: 468

FLANO E, HUSAIN SM, SAMPLE JT, WOODLAND DL, BLACKMAN MA 2000: Latent murine gammaherpesvirus is established in activated B-cells, dendritic cells and macrophages. J Immunol 165: 1074-1081

KONDO K, KONDO T, OKUNO T, TAKAHASHI M, YAMANISHI K 1991: Latent human herpesvirus 6 infection of human monocytes/macrophages. J Gen Virol 72: 1401-1408

KOŽUCH O, REICHEL M, LEŠŠO J, REMEŇOVÁ A, LABUDA M, LYSÝ J, MISTRÍKOVÁ J 1993: Further isolation of murine herpesvirus from small mammals in Southwestern Slovakia. Acta Virol 37: 101-105

LARSSON S, SODERBERG-NAUCLER C, MOLLER E 1998: Productive cytomegalovirus (CMV) infection exclusively in CD13-positive peripheral blood mononuclear cells from CMV-infected individuals: implications for prevention of CMV transmission. Transplantation. 65: 411-415

MACIEJEWSKI JP, BURENING ED, DONAHUE RE, SELLERS SE, CARTER C, YOUNG NS, STJEOR S. 1993: Infection of mononucleated phagocytes with human cytomegalovirus. Virology 195: 326-336

MATUŠKOVÁ M, MISTRÍKOVÁ J, MRMUSOVÁ M, ŽILKA N, STANČEKOVÁ M, KONTSEKOVÁ E 2003: Antigenic relationship between five isolates of murine gammaherpesvirus analyzed with monoclonal antibodies. Arch Virol 148: 1027-1036

MISTRÍKOVÁ J, BLAŠKOVIČ D 1985: Ecology of the murine alphaherpesvirus and its isolation from lung of rodents in cell culture. Acta Virol 29: 312-317

MISTRÍKOVÁ J, REMEŇOVÁ A, LEŠŠO J, STANČEKOVÁ M 1994: Replication and persistence of murine herpesvirus 72 in lymphatic system and peripheral blood mononuclear cells of BALB/c mice. Acta Virol 38: 151-156

MISTRÍKOVÁ J, MOŚKO T, MRMUSOVÁ M 2002: Pathogenetic characterization of a mouse herpesvirus isolate Šumava. Acta Virol 46: 41-46 
MRMUSOVÁ-ŠUPOLÍKOVÁ M, PAPPOVÁ M, MISTRÍKOVÁ J 2003: Pathogenesis of murine lymphotropic gammaherpesvirus isolate 78. Acta Vet Brno 72: 371-377

REICHEL M, MATIS J, LEŠŠO J, STANČEKOVÁ M 1991: Polypeptides synthetized in rabbit cells infected with murine herpesvirus (MHV): a comparison of proteins specified by various MHV strains. Acta Virol 35: 268-73

SAVARD M, BÉLANGER C, TARDIF M, GOURDE P, FLAMAND L, GOSSELIN J 2000: Infection of Primary Human Monocytes by Epstein-Barr Virus. J Virol 74: 2612-2619

SHIMAKAGE M, KAMURA M, YANOMA S, IBE M, YOKOTA S, TSUJINO G, KOZUKA T, DEZAWA T, TAMURA S, OHSHIMA A, YUTSUDO M, HAKURA A 1999: Expression of latent and replicative infection genes of Epstein-Barr virus in macrophage. Arch Virol 144: 157-166

SVOBODOVÁ J, STANČEKOVÁ M, BLAŠKOVIČ D, MISTRÍKOVÁ J, LEŠŠO J, RUSS G, MASÁROVÁ $P$ 1982: Antigenic relatedness of alphaherpesviruses isolated from free living rodents. Acta Virol 26: 438-443

SUNIL-CHANDRA NP, ARNO J, FAZAKERLEY J, NASH AA 1994: Lymphoproliferative disease in mice infected with murine gammaherpesvirus 68. Am J Pathol 145: 818-826

WECK KE, KIM SS, VIRGINIV HW, SPECK SH 1999: Macrophages are the major reservoir of latent murine gammaherpesvirus 68 in peritoneal cells. J Virol 73: 3273-83 
Plate V

Spiššáková I. . et al.: The Role of Alveolar ... pp. 353-359

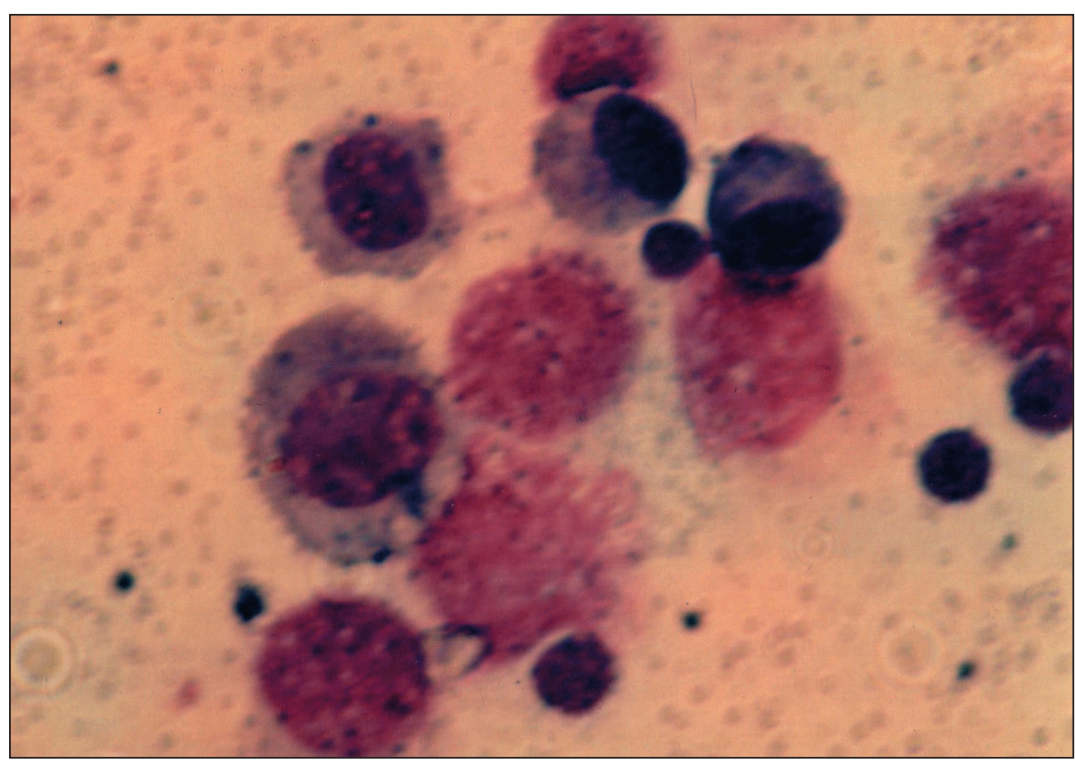

Fig. 1. Heterogenic population in PECs obtained from MHV-Š infected mice

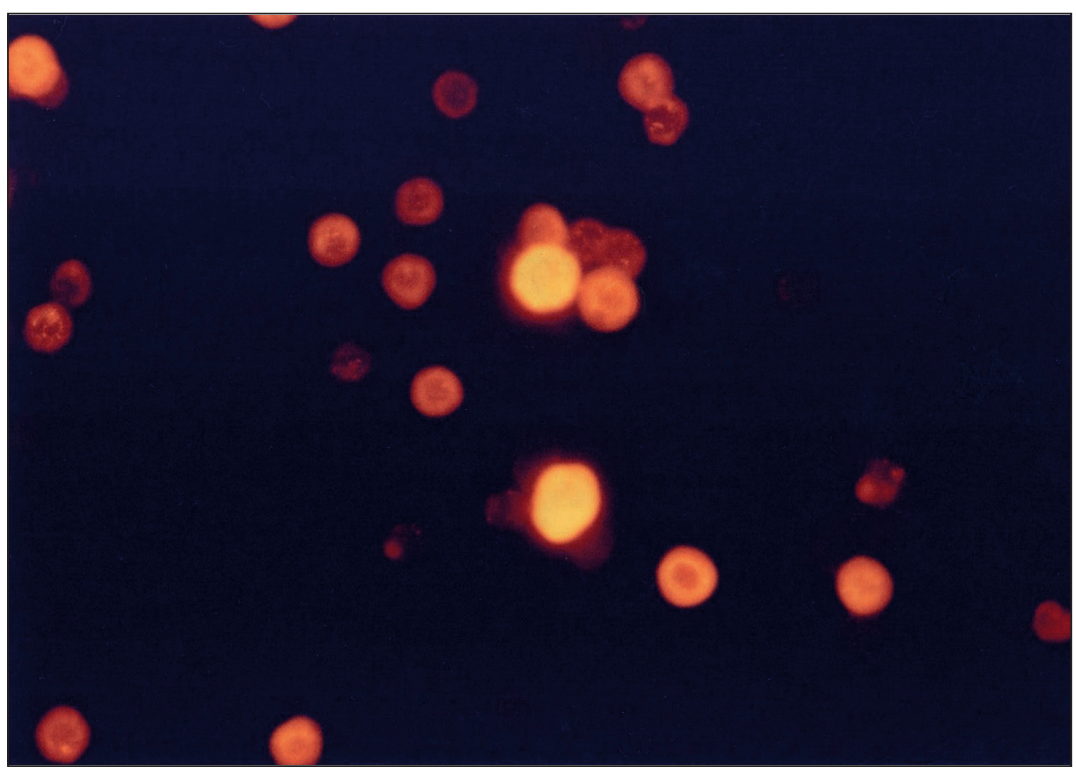

Fig. 2. Detection of viral antigen of MHV-S̆ 
Plate VI

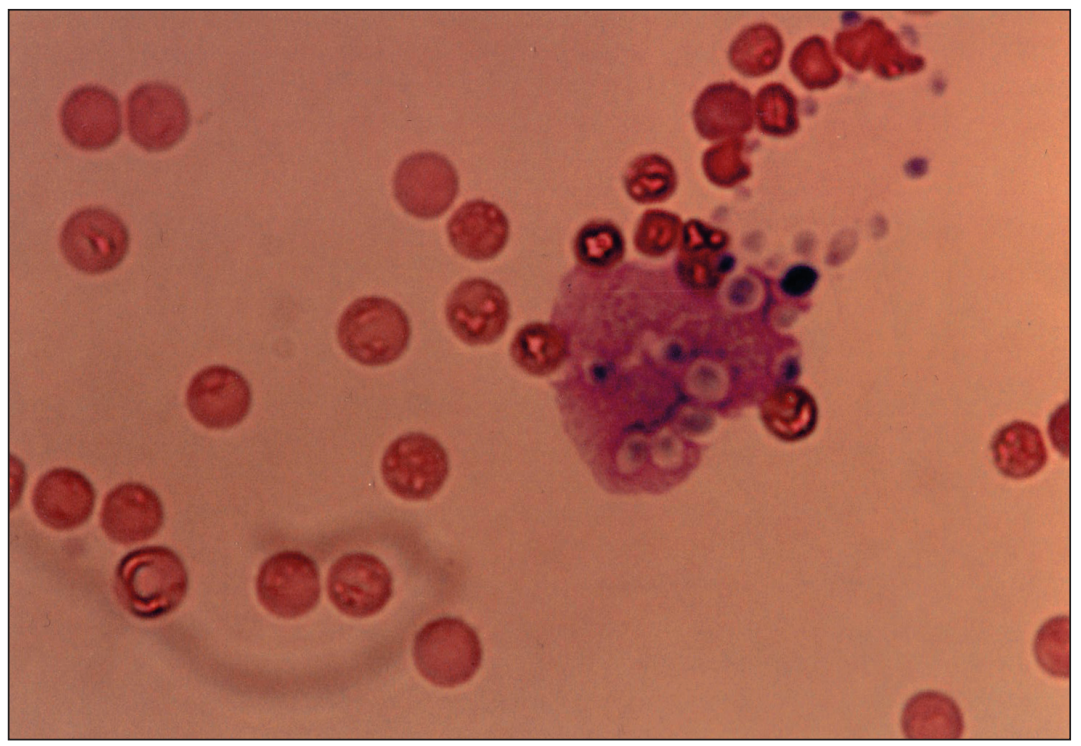

Fig. 3. Blood phagocyte engulfing Candida albicans after MHV-Šumava infection 